\title{
Causes and effects of conflicts between cattle herders and crop farmers in Girei, Adamawa State, Nigeria
}

Yahya, M. M. and Ahmed, M. M

Department of Animal Science

Modibbo Adama University of Technology, Yola.

Corresponding author: Muktarmagaji29@gmail.com

Abstract

Crop farmers and cattle herders' conflict have remained the most prevailing resource-use conflict in Girei Local Government Area of Adamawa State. Social and economic factors confined to inflame violent conflicts. The competition between these two Agricultural land user-groups threats the means of survival in the study area. The study describes the socioeconomic characteristics of farmers and herders and determines the causes of conflict in the study area. Primary data collected using structured questionnaire were subjected to simple percentages and chi-square analysis. The study revealed that the major causes of conflict in the study area are the crop damage by cattle, and lawlessness in the society. The findings also revealed that loss of expected yield, loss of cattle and loss of human lives and properties are the major effects of conflict. The study also concludes that the conflicts sometimes spread and lead to ethnic clashes and armed robbery. Therefore, it is in the interest of the state to address the genuine needs of herders and crop farmers since these two provides employment for almost all the rural people. In order to put an end to this conflict, it is therefore recommended that strange faces identified should be reported and leaders should preach the implications of conflict in the society.

Keywords: Clashes, Conflict, Farmers, Herders and Lawlessness

\section{Des Causes et des effets des conflits entre éleveurs et agriculteurs à Girei, de l'État d'Adamawa, Nigéria}

\section{Résumé}

Le conflit entre les agriculteurs et les éleveurs de bétail pose un grand problème qui est le plus répandu dans la région du gouvernement local de Girei, dans l'État d'Adamawa. Les facteurs sociaux et économiques servent à enflammer des conflits violents. La concurrence entre ces deux groupes d'usagers des terres agricoles menace les moyens de survie dans la zone d'étude. L'étude décrit les caractéristiques socio-économiques des agriculteurs et des éleveurs et détermine les causes des conflits dans la zone d'étude. Les données primaires collectées à l'aide d'un questionnaire structuré ont été soumises à des pourcentages simples et à une analyse du chi carré. L'étude a révélé que les principales causes de conflit dans la zone d'étude sont les dommages causés aux cultures par le bétail et l'anarchie dans la société. Les résultats ont également révélé que la perte de rendement, la perte de bétail et la perte de vies humaines et de propriétés sont les principaux effets du conflit. L'étude conclut également que les conflits se propagent parfois et conduisent à des affrontements ethniques et des vols à main armée. Il est donc dans l'intérêt de l'État de répondre aux besoins réels des éleveurs et des agriculteurs, car ces deux moyens fournissent des emplois à presque tous les ruraux. Afin de mettre un terme à ce conflit, il est donc recommandé de signaler les visages étranges identifiés et les dirigeants devraient sensibiliser aux implications des conflits dans la société.

Mots clés : affrontements, conflits, agriculteurs, éleveurs et anarchie 


\section{Causes and effects of conflicts between cattle herders and crop farmers in Girei}

\section{Introduction}

One major problem confronting world peace today is the manifestation of conflict in different dimensions across the globe. From Europe to America, Africa to Asia conflicts are common (Jeong, 2008). Conflicts have been defined in different ways by different scholars. Ekong (2003) defined conflict as the form of social interaction in which the actors seek to obtained scarce reward by eliminating or weakening their contenders. Nigeria has experienced and still experiencing conflicts on grave proportions among several ethnic and religious communities. These conflicts vary in dimension, process and groups involved. It was observed by Momale (2003) that while some conflicts arise between same resources user groups, others occur between different user groups such as herders and farmers. Adisa (2012) observed that the crop farmers' conflict has remained the most preponderant resources-use conflict in Nigeria. Social and economic factors continue to provide violent conflicts among the Fulani pastoralist and crop farmers. The intensity and variation of the conflict largely depend on the nature and type of the user groups where the pastoralist grazes. The conflicts over access right to farmland and cattle routes have become ubiquitous and seem to have defied solutions (Abbas, 2009). However, Coser (2000) have noted that, the inevitability of conflict in the claim for scarce resources is considered as the bane for struggles over the inestimable value for land and its resource, with the claim for ownership and the claim for its position as a common resource. Historical tension between pastoralist and settled indigenous crop farmers have intensified in recent years with dwindling natural resources and land availability greatly contributing to the ongoing, escalating conflict in the country (Okello et al., 2014). The herdsmen-crop farmers' conflict is now very rampant that almost every settlement that contains both herders and crop farmers are facing. This study tends to describe the socio-economic characteristics of the respondents, examine the factors responsible for the conflict and determine the major effects of conflicts in the study area.

\section{Materials and methods}

The study was conducted in Girei Local Government Area of Adamawa State. It is an agrarian area well suited for rain fed and irrigation due to the presence of the river Benue in the area. Farming is the main occupation of the people with emphasis on the cultivation of vegetables crops like tomatoes, pepper, onion, carrots and cabbage are grown. Some of the farmers are involved in livestock keeping, but Fulani herdsmen dominate the rearing of livestock in the area. It is located in the central area of Adamawa State. It is located on latitude $9^{0}$ $14^{\prime} \mathrm{N}$ and longitude $12^{\circ} 28^{\prime} \mathrm{E}$ and occupies a land mass of $8,068 \mathrm{~km}^{2}$ with an altitude of about $185.9 \mathrm{~m}$ above sea level and posses two distinct seasons which are rainy and dry seasons (Adebayo, 2004).

\section{Sampling procedure and sampling size}

A multi-stage sampling procedure was used for the study. In the first stage, 3 villages were sampled from a population of 15 villages that made the study area. The purposive selection was made because the sampled area consists of villages where crop farmers and cattle herders' conflict occur frequently. The selected villages for the study were Koh, Labondo and Gereng. A total of 5 crop farmers and 5 cattle herders from each of the 3 villages in the Local Government Area were chosen randomly, thus giving a total of 15 crop farmers and 15 cattle herders.

\section{Method of data collection}

Primary data was collected for the study. The data was obtained through field survey 


\section{Yahya and Ahmed}

using structured questionnaire. A total of 30 questionnaires were administered throughout the selected three (3) selected villages.

\section{Analytical techniques}

The data collected were analyzed using descriptive statistics, specifically frequently counts and percentages while chi-square analysis was also used to achieve the objectives.

\section{Results and discussion}

The results of the socio-economic characteristics of the respondents as presented in Table 1 shows that majority $86.21 \%$ ) of the respondents were males while $13.79 \%$ were females, most (89.66\%) of the respondents are married which only $10.34 \%$ were females, most $(89.66 \%)$ of the respondents are married which only $10.34 \%$ were single. The study also revealed that most $(62.07 \%)$ were between the ages of $30-40$ years, while $21.17 \%$ were above 40 years of which only $13.79 \%$ are below 30years, $58.62 \%$ of the respondents have $6-10$ children, $20.69 \%$ have $11-15$ children while only $6.90 \%$ have more than 15 children. The study also revealed that $41.38 \%$ are crop farmers, $34.48 \%$ are cattle rearers and 24.14 are those that combine crop farming and cattle rearing. Respondents' level of education shows that $51.73 \%$ attended only Quranic schools, $34.48 \%$ are primary certificate holders, $13.79 \%$ are secondary school certificate holders and none studied beyond secondary school. The result also shows that $17.24 \%$ of the respondents are Hausa, 13.79\% are others who are mostly Sullubawa (cattle herders) and few Kanuri farmers and majority $(68.97 \%)$ are Fulanis. This report is close to the findings of Akinola and Ironkwe (2012) who reported that $63.8 \%$ male and $36.2 \%$ female, $53.7 \%$ were of ages between $41-50 y e a r s, 25.43 \%$ and 31.3 of the respondents had Primary, Secondary and Tertiary certificates in Rivers State respectively. Socio-economic features of ruminant animal marketers in Alaba-Rago market in Lagos shows that $83.93 \%$ are male, $64.29 \%$ married, $16.07 \%$ were widows, $53.57 \%$ were within the ages of 31-49 years, while $47.32 \%$ had Primary certificates. Moreover, $33.04 \%$ had SSCE/OL, $10.71 \%$ possessed OND/NCE wheraes $7.14 \%$ had B.Sc/HND and only $1.79 \%$ had M.Sc respectively (Lamidi et al., 2012). The major causes of conflict in the area as revealed by the study were due to damage emanating from both cattle and lawlessness in the society leading to loss of crops and animals as well as human lives. The study of crop farmers and cattle herders' conflict cannot be complete without looking at the courses of the conflict. The common courses have been analyzed in Table 2 . It shows that $41.38 \%$ of the respondents agreed that accessibility of natural resources as a course of famers' conflict, $34.48 \%$ agreed, $17.24 \%$ disagreed and only $6.10 \%$ disagreed. The research also revealed that $86.20 \%$ of the respondent strongly agreed that damage of crops by cattle is a course of crop famers and cattle herders' conflict, $6.90 \%$ agreed, $3.45 \%$ disagreed and $3.45 \%$ strongly disagreed. The study also indicates that $79.31 \%$ strongly agreed that lawlessness in the society is a course of famers conflict, $19.34 \%$ agreed, $6.90 \%$ disagreed and $3.45 \%$ strongly disagreed. The study revealed that accessibility of natural resources like grass and water, damage of crops by cattle and lawlessness in the society are the courses of famers conflict in Girei Local Government Area of Adamawa State, Nigeria. Nweze et al. (2012) reported that pastoralist occasionally clash with native arable crop famers due to livestock encroachment on their crops which could be attributed to forage scarcity on range land. Range land resource inventory is 
Causes and effects of conflicts between cattle herders and crop farmers in Girei

Table 1: Socio-economics characteristics of the respondents

\begin{tabular}{lcclcc}
\hline Variable & Frequency & Percent (\%) & Variable & Frequency & Percent (\%) \\
\hline Gender & & & Educational Level & & \\
Male & 25 & 86.21 & Quranic & 15 & 51.73 \\
Female & 4 & 13.79 & $\begin{array}{l}\text { Primary School } \\
\text { Secondary School }\end{array}$ & 10 & 34.48 \\
& & & Tertiary Institution & 0 & 13.79 \\
Marital status & & & Age & & 0.00 \\
Married & 26 & 89.66 & $20-29$ & 4 & \\
Single & 3 & 10.34 & $30-39$ & 18 & 13.79 \\
Household size & & & 40 and above & 7 & 24.14 \\
$>5$ & 4 & 13.79 & Occupation & 12 & 51.38 \\
6-10 & 17 & 58.62 & Cattle Rearing & 10 & 24.48 \\
$11-15$ & 6 & 20.69 & Both & 7 & \\
16 and above & 2 & 6.90 & & & \\
Ethnic Group & & & & & \\
Hausa & 5 & 17.24 & & & \\
Fulani & 20 & 68.97 & & & \\
Others & 4 & 13.79 & & & \\
\hline
\end{tabular}

Table 2: Courses of crop famers and cattle herders' conflict

\begin{tabular}{llllllllc}
\hline Parameter & \multicolumn{2}{c}{$\begin{array}{l}\text { Strongly } \\
\text { Agreed }\end{array}$} & \multicolumn{2}{c}{ Agreed } & \multicolumn{2}{c}{ Disagreed } & \multicolumn{2}{c}{$\begin{array}{l}\text { Strongly } \\
\text { disagreed }\end{array}$} \\
& F & $\mathbf{\%}$ & F & \% & F & \% & F & \% \\
\hline Accessibility of natural resources & 12 & 41.38 & 10 & 34.48 & 5 & 17.24 & 2 & 6.10 \\
& & & & & & & & \\
Damage of Crops by Cattles & 25 & 86.20 & 2 & 6.90 & 1 & 3.45 & 1 & 3.45 \\
Lawlessness in the Society & 23 & 79.31 & 3 & 10.54 & 2. & 6.90 & 1 & 3.45 \\
\hline
\end{tabular}

$\mathrm{SA}=$ Strongly Agreed, $\mathrm{A}=$ Agreed, $\mathrm{D}=$ Disagreed, $\mathrm{SD}=$ Strongly Disagreed, F $=$ Frequency

necessary to provide data for viable range Land planning. They also reported that increase in animal stock density have increased the level of communal conflict in the study area between the native arable crops famers and nomadic cattle herders. Basil (2017) also reported that the effect of climate change on environment which result to drought, acute water scarcity, dry and scarce forages course the nomadic transhumant migration of pastoral herds men from their base to else where with the consequent trespass to famer land and other places not suitable for raising livestock lead to both human and material damage. It can be minute and of no significance at initial time but could be dangerous and even sprayed to many parts if nor resolved promptly. The situation can be transferred from one generation to another.

The results in Table 3 show the common causes of crops famers and cattle herders conflict in the study area. The study revealed that $65.52 \%$ of the respondents have lost their expected yield due to conflict, while $34.48 \%$ did not lose their expected yield. Among those that lost their yield, 20.69\% lost sorghum, 31.04\% maize and $13.79 \%$ other crops which are mostly beans and groundnut. The results also revealed that $27.59 \%$ lost their cattle, $48.27 \%$ sheep and $10.4 \%$ goats. As a result of conflict, the research also revealed that $62.07 \%$ of the respondents lost members of their households whereas $37.39 \%$ did not lose any member of their family. Out of 
Yahya and Ahmed

Table 3: Causes of Crop Farmers and Cattle Herders Conflict

\begin{tabular}{|c|c|c|c|c|c|}
\hline Parameter & Frequency & Percent (\%) & Parameter & Frequency & Percent (\%) \\
\hline Have you lost & & & If yes, which & & \\
\hline your expected & & & Animal? & 8 & 27.59 \\
\hline yield? & & & Cattle & 14 & $48 . .34$ \\
\hline Yes & 19 & 65.52 & Sheep & 3 & 10.34 \\
\hline No & 10 & 34.48 & Goat & & \\
\hline $\begin{array}{l}\text { If yes, which } \\
\text { crop? }\end{array}$ & & & $\begin{array}{l}\text { Have you lost } \\
\text { your } f \quad \text { amily }\end{array}$ & & \\
\hline Sorghum & 6 & 20.69 & member? & 18 & 62.07 \\
\hline Maize & 9 & 31.04 & Yes & 11 & 37.93 \\
\hline Others & 4 & 13.79 & No & & \\
\hline Have you ever & & & If yes, how & & \\
\hline lost livestock? & & & many? & 21 & 72.41 \\
\hline Yes & 15 & 51.72 & 1 Person & 5 & 17.25 \\
\hline \multirow[t]{4}{*}{ No } & 14 & 48.28 & 2 Persons & 3 & $10 . .34$ \\
\hline & & & 3 Persons & 0 & 0 \\
\hline & & & More than & & \\
\hline & & & Persons & & \\
\hline
\end{tabular}

those that lost their family members, $72.41 \%$ lost only one person, $17.25 \%$ lost two people, $10.34 \%$ lost three, while no household lost more than three people. The findings therefore, indicate that each of the conflict causes reported above affects most of the respondents. This corroborates with the findings of Mohammed and Mahdi (2005) who reported that the pastoralists are always on the move and as such they trespass into other people holdings and damage their crops and properties which results in to communal clash. Similarly, Basil (2017) reported that States such as Plateau, Benue, Taraba, Nasarawa and many southern States have multiple complains of conflict as a result of animals destroying their valuable crops and some times invasion of community by herds men at night or on market days, this lead to under development, lost of economic values, displacement of homes and loss of lives and sometimes war.

\section{References}

Abba, I. M. 2009. No Retreat No Surrender conflict for survival between
Fulani cattle Herders and Farmers in Northern Nigeria. European Scientific Journal 8(1) 331-349.

Adisa, R. S. 2012. Land use conflict between Farmers and Herdsmenimplications for Agricultural and Rural Development.Department of Agricultural Exention and Rural Development, University of Ilorin, Ilorin Nigeria.

Adebayo, A. A. and Tukur, A. L. 1999. Adamawa State in Maps Paraclete publications, Yola

Akinola, L. A. F. and Ironkwe, M. O. 2002. An Assessment of the Awareness level of occupational and Environmental Hazards among poultry farmers in Rivers State, Nigeria. Proceedings of $17^{\text {th }}$ Annual conference of ASAN/NIAS, Abuja.

Basil, O. N. 2017. Nigerian Pastoral Farming and pasture production. Dika's publishing company. Abakaliki, Ebonyi State/

Coser, L. A. 2000. Continuities in the study of social conflict. London. MacMillan Publishers. 
Ekong, E. E. 2003. An Introduction to Rural Sociology. $2^{\text {nd }}$ Edition. Dove of Educational publishers, Uyo, Nigeria.

Jeong, H. 2008. Understanding conflict and confilict Analysis. London: Sage Publication..

Lamidi, A. A., Ashorun, W. O. and Aregbosola, A. O. 2012 . Economics of Ruminant Animal marketing in Lagos Metropolis: a case study of Alaba-Market. Proceedings of $17^{\text {th }}$ Annual conference of ASAN/NIAS, Abuja.

Mohammed, B. and Sahabo, M. 2005. A compendium of studies and issues in pastoralism in Nigeria. Paraclet publishers Yola Nigeria

Momale, S. B. 2003. Resource use Conflict in Agricultural and Pastoral area in Nigeria. In Gefu, J.. O. (Ed). Land Tenure system in Nigeria.
Nwenze, B. O., Ekwe, O. O., Ebenebe, C. I. and Nwosu, E. U. 2012. Characterization and productivity of pasture species on Eboni range land. Proceedings of $17^{\text {th }}$ annual conference on Animal Science Association of Nigeria, 9-13 September, 2012, Abua.

Okello, A. L., Majekodunmi, A. O., Malala, A., Welburn, S. C. and Smith, J. 2014. Identifying motivators for state Pastoralist Dialogue.

Received: $14^{\text {th }}$ June, 2020

Accepted: $20^{\text {th }}$ December, 2020 